\title{
Image of the Builder of Communism in the Soviet Posters
}

\author{
Artur Dydrov \\ South Ural State University, Russia. Email: dydrovaa@gmail.com
}

Received July o1, 2016; Revised December 09, 2016; Accepted December 21, 2016; Published January 14, 2017

\begin{abstract}
This paper focuses on the image of the Soviet people - builders of communism. The object of the study is a series of Soviet posters in different years. In this paper semiotic approach has been used to consider posters as signs. Each poster is a product of the ideology on a denotative and connotative level of the sign. For semiotics verbal messages, color, perspective, the value of the figures, postures, gestures and facial expressions are important. Poster is a complex of the two-roots system. It combines verbal and iconic messages. Images of the Soviet human were constructed from various combinations of the elements from these levels.
\end{abstract}

Keywords: Soviet poster, Soviet people, the Soviet Union, ideology, connotation, semiotics.

\section{Introduction}

Soviet political leaders, who had rethought the Marxist theory of socialism and communism, declared the establishment of a new society, which would jump in the "realm of freedom". Marked as "the dictatorship of the proletariat", "socialist camp", "socialist state of workers and peasants", "developed socialist society" ext., the USSR and its political system was ideologically oriented to the construction of communism.

Doctrine of communism was expressed in the speeches of politicians, in the media and arts. In the arts, the ruling "method" was socialist realism. Artistic conception of socialist realism has been fixed in many papers (for example, Kiaer, 2014: 56-77; Kiaer, 2014: 321-345, ext.). I. Kukulin in his article "Privatization of a Riot: 'Second Life' of the Early Soviet Montage" also studied the problems of social realism. The socialist realist depicts a human as a builder of communism. Communist human was portrayed in cinema, literature and painting. Images of the human of the future - the builder of communism - repeatedly appeared in the poster art.

A lot of articles has been written about the poster art (Dymarczyk, 2014: 6-31; Kuzmina, 2014: 55-66; Edele: 89-108). Poster art was primarily an ideological instrument of influence on the Soviet citizens. The poster has certain advantages; first, posters can be seen on the streets, in the villages; secondly, posters can be relatively easily replicated; third (and the main) posters specifically broadcast messages. We are interested in the last aspect more than the others.

If we look at the poster as means of storage, expression and transmission of the message, as a carrier of information, the semiotic approach becomes important. Soviet socialist realism was a multi-faceted cultural and artistic movement. And it can be regarded as the element of "semiosphere" or, in the words of Y. Lotman, as the "semiotic continuum" (Lotman, 2002: 64). The Soviet poster art was one of the areas of the semiosphere, the elements of which are available to the

(c) AesthetixMS 2016. This Open Access article is published under a Creative Commons Attribution Non-Commercial 4.0 International License (http://creativecommons.org/licenses/by-nc/4.o/), which permits non-commercial re-use, distribution, and reproduction in any medium, provided the original work is properly cited. For citation use the DOI. For commercial re-use, please contact editor@rupkatha.com. 
masses and do not require any preparation for readers and viewers. It is natural that the image of the communist human arose precisely in the Soviet poster art. The image of the communist human is woven from words and strokes of turns of speech, outlines of shapes, colors, gestures, postures, and so on. In this paper, I also rely on research of A. Solomonik ("Positive Semiotics", "The Paradigm of Semiotics"). A. Solomonik introduced into scientific circulation the concept of quantum of abstract the sign (Solomonik, 2011: 12). The Israeli researcher isolated the natural, imaginative, language sign systems and the recording system, code system. The poster art combines the two systems -language and imaginative. Their combination is not universally valid. But the work with extensive empirical material convinces another. Image and verbal communication are inextricably linked. In the article "Semiotics of the Soviet Poster of the Great Patriotic War" I discussed an example. In 1941 Soviet poster artist N. Vitolina depicted a woman in a red dress and shawl. It shows a finger at the smoking ruins of several buildings. This poster would call for careful handling of fire. But in combination with the word "fascism - the worst enemy of women ..." poster has a different meaning. Ruins, smoke, death are the consequences of the Nazi attack on the Soviet people. The bond strength of the image and verbal communication is undeniable. It is characteristic for the builders of communism on posters. In this article I will analyze the iconic series and verbal messages.

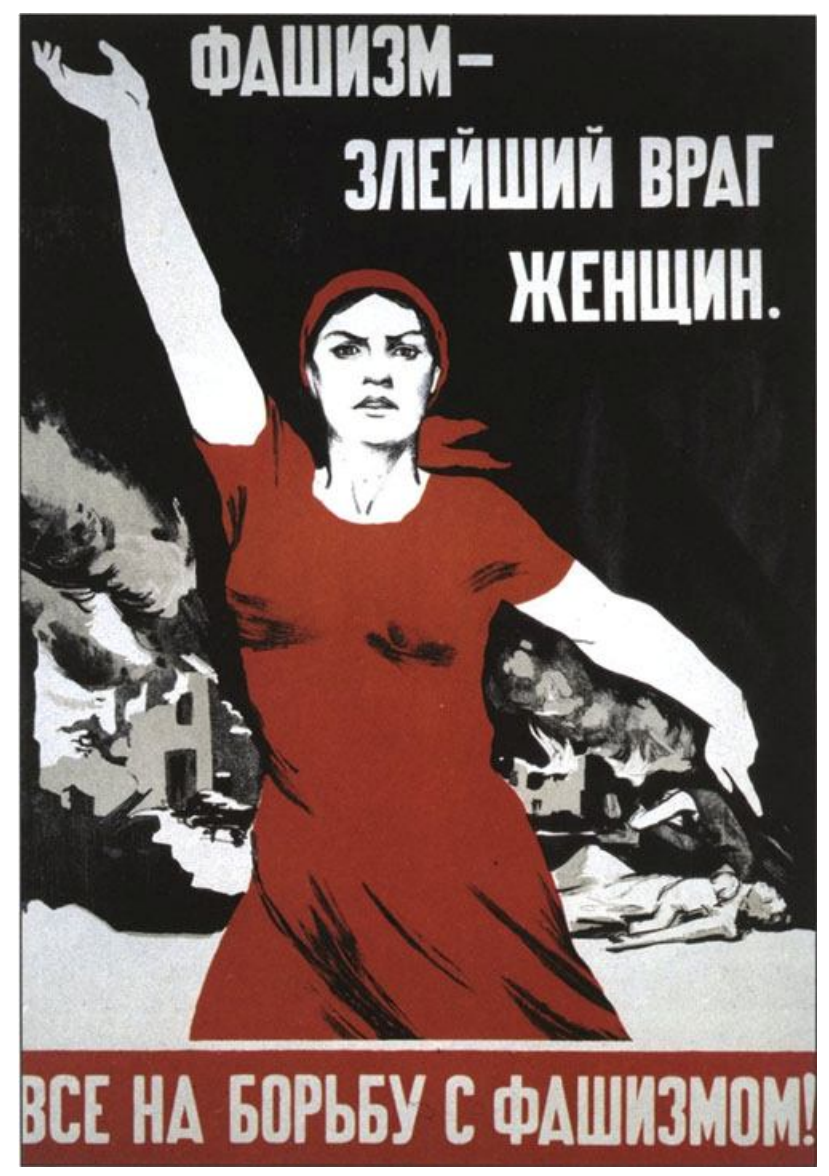

Figure 1: Poster by N. Vitolina

\section{Iconic Posts in Soviet Poster}

R. Barthes in his article "The Rhetoric of the Image" wrote about the iconic messages. Any iconic message includes shapes, colors and the image collection of objects. These items need to be 
identified. They are organized in the "space" of the poster. In addition, the iconic message may delaminate (Barth, 1989: 297-298). There are images with code and images without code. The images without code are tightly bound to the referent. They can be understood literally. The ideologues like and want it. Consider V. Ivanov's poster "The Great Stalin - the Torch of Communism" (1949). The poster shows the party's secretary general. He is holding a smoking pipe. His other hand holds the book of Lenin. The office has a bookcase. But all that could tell anyone. What else sends a message?

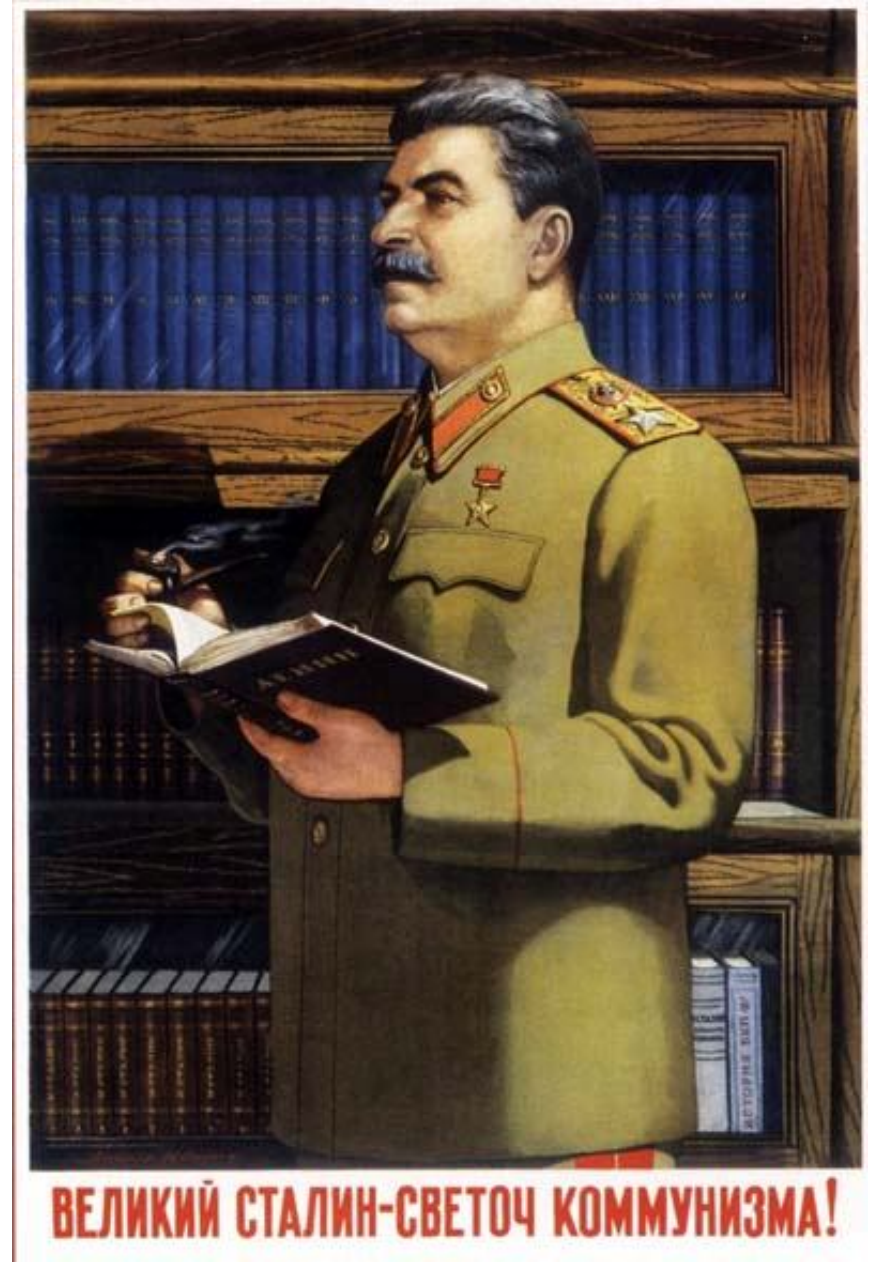

Figure 2: Ivanov's poster “The Great Stalin - the Torch of Communism”

Barthes pointed to another level of iconic message, which one cannot see. Barthes called it a "symbolic" and "connotative" (Barthes, 1989: 302). First level is the surface or denotation. The leader's look is into the distance. The author of the book is V. Lenin - the founder of the Soviet state. On the shelves are clearly visible bindings of books of I. Stalin. And they are multi-product. First, the poster conveys the idea of continuity of government (the course of V. Lenin - I. Stalin). Secondly, the wisdom of the head. He forgot about the pipe. The Secretary-General is not just reading, but also considering the reading. The book is the source of his thoughts, ideas and reforms. In addition, he wrote and is writing. He is a creative person. He has the responsibility of the government's decision-making. He justifies the hopes of the people. The image of I. Stalin has romanticism. Looking into the distance is strongly associated with thoughts about the future. This applies primarily to the depicted heads of the states. This was the romantic image of Mao Zedong. 
The Chinese' leader was shown in the background of the sea and the developing red flag. Looking into the distance is the attribute of the canonical image of Che Guevara, and so on.

Continuity of the state leaders was expressed in poster "In the Name of Communism" by V. Govorkov (1951). The poster depicts the figures of V. Lenin and I. Stalin facing each other. The views of the leaders are chained to the plan area. Both of them draw something on the map. Tube and books are also shown to the viewers. The leaders solve the problems of the electrification and communications. Signs of electrification are marked on the background of the figures of leaders. In addition, this is clear and ongoing allusion to Stalin's industrialization policy. I. Stalin drew a red cross next to the image of the Turkmen channel. He crossed out the word "desert" in the phrase "Kara-Kum desert". Caring for the people in the head of the leader is combined with strategic thinking (working with the card). Facial expressions and posture of leaders speak about the absolute concentration, a giant effort of thought. Much has been done (map on the wall behind the figure of I. Stalin). But one day the Soviet people would subordinate the nature and destroy the desert. In place of the desert would be draped pockets of civilization and centers of life. Back in the '2os and ' 30 os in the USSR there was a set of literary utopia. These works were dedicated to the future of the Soviet people. One of the main ideas of the Soviet utopias is connected with the relationship of human to nature. The human would conquer nature and force her to serve the public good. The builders of communism reshape the landscape. The human of the future would regulate the climate. Natural barriers (mountains, rivers etc) will no longer interfere with the achievement of the goals.

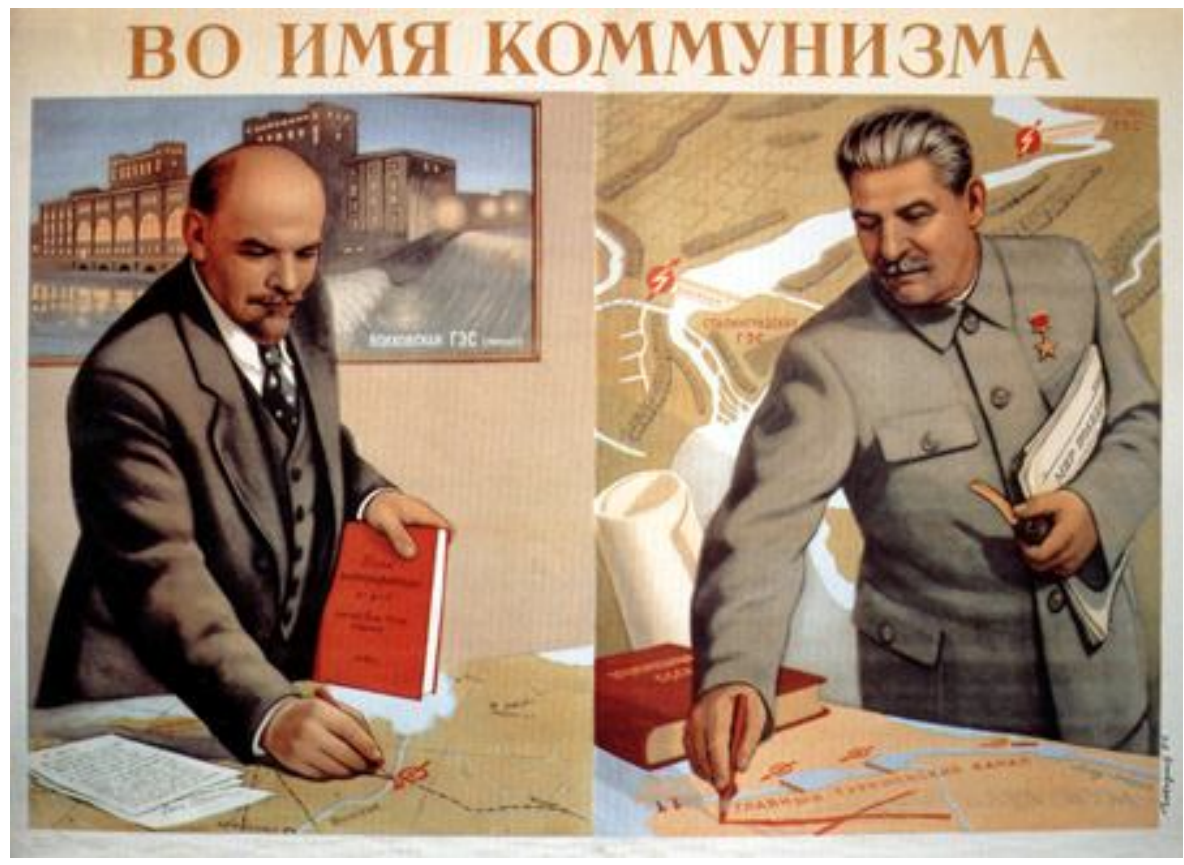

Figure 3: "In the Name of Communism" by V. Govorkov (1951)

In the Soviet posters messages about the construction of communism is firmly linked with the portraits of heads of state and party secretaries. With the meaning of communism inseparable are the figures of V. Lenin, I. Stalin, N. Khrushchev, L. Brezhnev and others. "Communism - Soviet power + electrification" - is the inscription on the poster with the image of V. Lenin. The poster "Forward to the victory of communism!" depicts I. Stalin against the backdrop of a crowd with red flags. "So let's go boldly forward on the path to communism" - a poster presented photos of L. Brezhnev against a red flag with a profile of V. Lenin. 


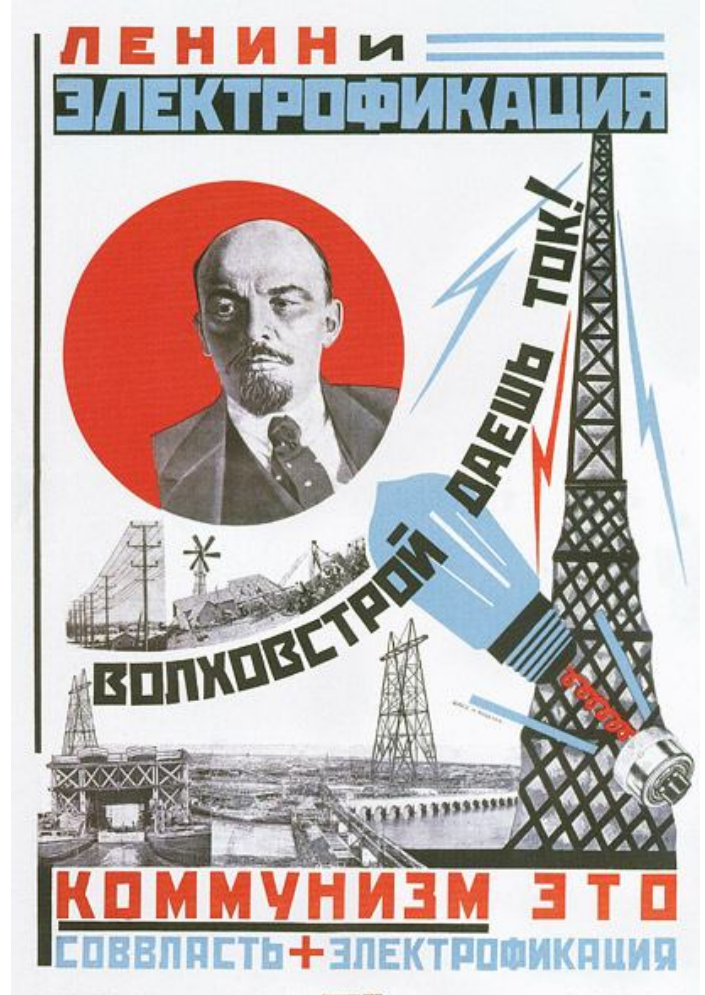

Figure 4: "Communism - Soviet power + electrification"

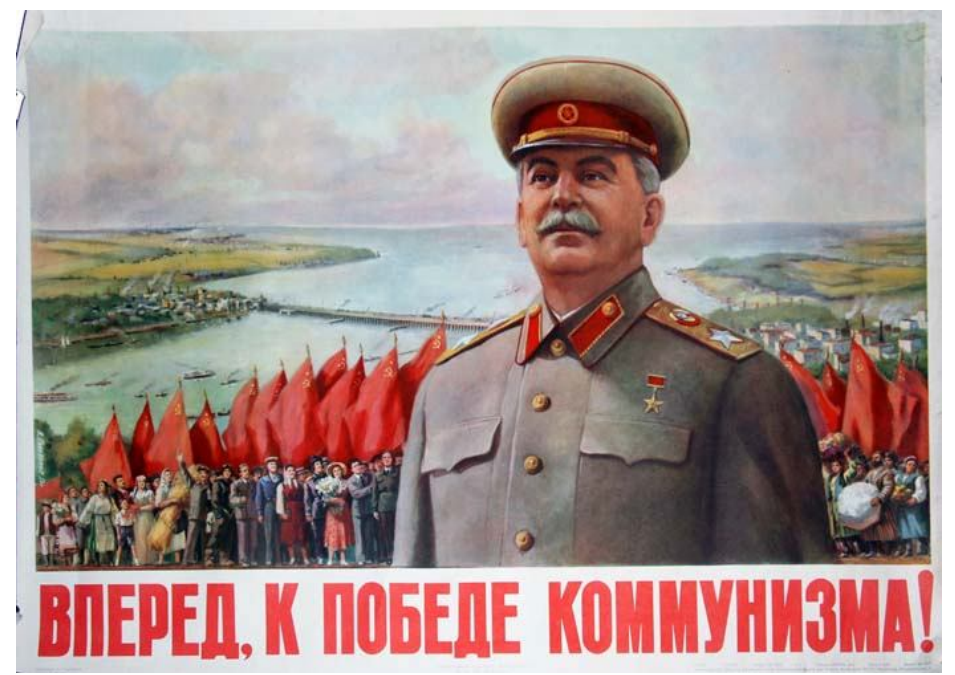

Figure 5: "Forward to the victory of communism!"

Stylized images of Soviet leaders are the one of the markers of poster art. Images of the Secretaries-General and construction projects of communism almost merge. Without much effort, you can read the iconic messages and identify some of the distinctive features of the Soviet political elite. I will outline them briefly:

1. Strategic thinking: Working with maps, diagrams, site plans, knowledge of the goals and means of achieving the desired results, looking into the distance, into the future, the role of the architect (Stalin - "architect"). 
2. Decisiveness: Strikethrough the desert is the equivalent to its destruction as unconditional adherence to the course.

3. Large creativity: I. Stalin's and V. Lenin's books on the bookshelves.

4. High level of education: Reading and analysis, the experience of reading.

5. Lack of strategic and tactical errors: N. Khrushchev attacked I. Stalin at the XX Congress of the CPSU (1956). But I do not know the anti-Stalinist poster at the time of N. Khrushchev's rule.

Builders of communism were not only on the leaders of the Soviet state. The posters often had images of workers and peasants. These images cannot be ignored. Tools, methods of representation of the image of communist human are important. I will try to consistently consider iconic messages.

\section{The prospect of a poster. Gestures, facial expressions, posture}

Perspective, proportion, color and other elements play an important role in many figurative sign systems and, in particular, in visual arts. This is an area of interest for critics, artists, graphic artists and semioticians. P. Florensky persuasively argued that the prospect may be very important (Florenky, 2009). Space of the image is organized by the prospects. Perspective is also a "mirror" of the inner world of the author. Is the prospect directly an affect to the sign continuum? This question should be answered positively.

Let us focus on the Soviet posters of the Great Patriotic War. It depicts the prince (probably, A. Nevsky), Generalissimo A. Suvorov and the head of the division of the Red Army V. Chapaev. They are armed and ready to fight against the German invaders. But there is conventionality in their portraits:

i. The images are made in light red.

ii. The figures of historical figures are not proportional to the figures of soldiers.

iii. The military leaders of different eras present a united front. Legendary commanders are like the spirits, which go down to the soldiers as good geniuses.

The size of the figures of Soviet' leaders is a very important feature of any Soviet poster. Figure of I. Stalin and V. Lenin are consistently higher in comparison with the figures of ordinary builders of communism. The viewer should be confined primarily to leaders, prominent figures of the party, the first revolutionaries. The profile of V. Lenin was often depicted on the posters. In these cases, the dimensions of the profile were significantly larger than the working pieces. He was placed at the center of the image. And the look again was riveted to it. This is, of course, not the reverse, but linear perspective. Figures of workers, peasants and soldiers were shown in a direct linear perspective.

On the B. Belopolsky's poster "Glory to Stalin, the Great Architect of Communism!" (1951) the different plans are clearly shown (depending on the size of the figures). In the foreground there is the leader (the center of the composition). He holds a large folded sheet (plan, diagram) and pipes. Stalin's view is into the distance. The background shows the figure of engineers, technicians and workers, who are dressed in suits and coats. In te third plan we have small figures of people. Multi-figured compositions are not uncommon in painting (P. Brueghel, J. Bosch, B. Kustodiev, K. Korovin and others.). The artists of the poster continued this tradition. Smaller pieces are also playing a definite role. They gesticulate. People are waving their hands. This gesture - one of the 
most popular in the world - often means a greeting. Stalin, who is looking into the distance, welcomes all thanks contemporaries. They worked on the "great construction projects" and are now enjoying the "fruits" of common labor. Without Stalin's leadership, results obviously would not be achieved. The L. Golovanov's poster "Forward, to the victory of communism!" (1950, figure 4) figure of Stalin once again is at the center of the image. Stalin's look is directed "forward", into the future. Behind Stalin the crowd is depicted. The line went off the builders of communism. It 'cuts' the corner of the canvas. The viewer's attention moves on to a string of red banners. One of the characters welcomes the "architect" of communism. This "saving" is also expressive gestures. A small figure with a raised hand and open hand is the center of the second plan. The third plan - the river, the river steamers, smoking pipes and stretched the field, closes the composition. It shows the extent of change. The vast land of the Soviet state was behind Stalin. The figure of Stalin is a figure of the commander. The masses are "armed" with flags and go for their captain. "Forward, to the victory of communism!" is the poster-palimpsest. Similar compositions previously were created by Y. Kossak ("The Polish army"), A. Bubnov ("Morning on the Kulikovo Field") and others.

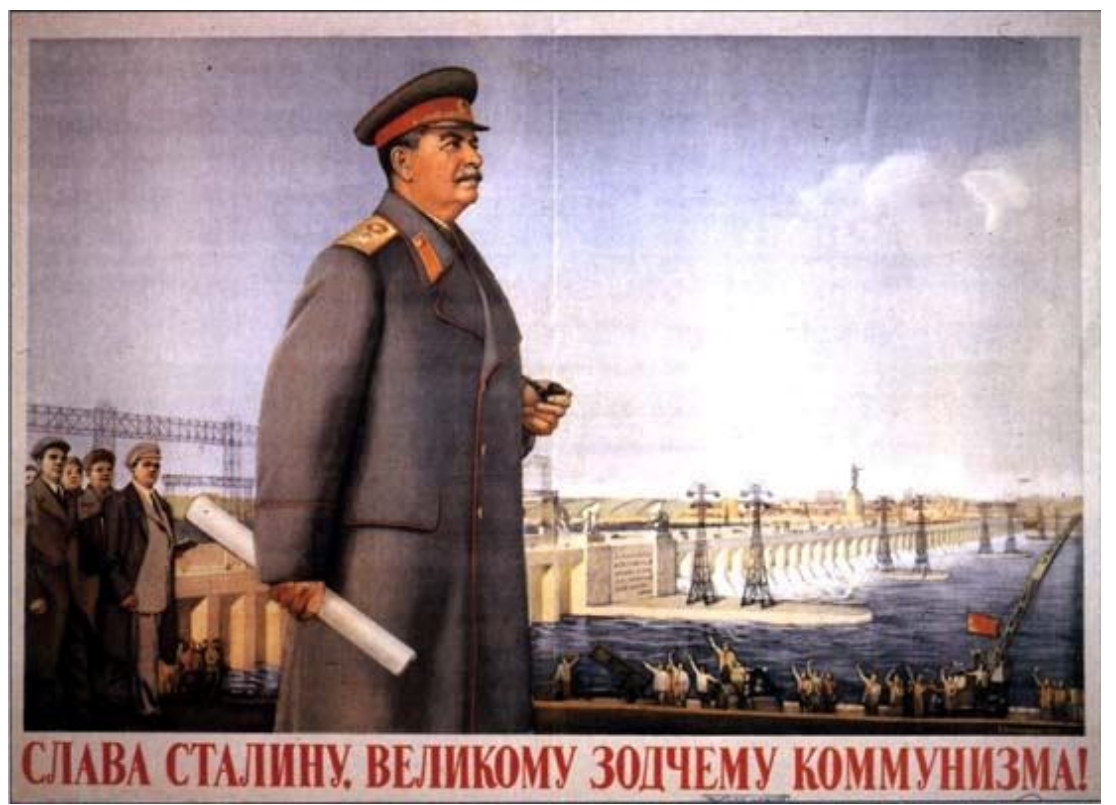

Figure 6: B. Belopolsky's poster “Glory to Stalin, the Great Architect of Communism!”

It is extremely difficult to say something definite about the facial expressions of the people. The poster "And drought we will win!" the artist depicted Stalin's face traced with wrinkles around the eyes. Stalin's squinting did not read as a sign of deceit or distrust. Squinting shows thoughtfulness. Stalin gazes into the future. Stalin also was portrayed with a slightly wrinkled forehead. This is certainly a sign of thinking and concentration. Often, on the contrary, it was a half-smile in the portrait of Stalin: 1. he leads the people and points the way for them; 2 . he casts votes in the ballot box ("For the happiness of the people", V. Ivanov, 1950); 3. he welcomes the Soviet people (“Glory to our great people!", N. Petrov, M. Abrams, 1948); 4. he is surrounded by Soviet children ("Thank dear Stalin for a happy childhood!", N. Vatolina, 1950). Persons of ordinary builders of communism expressed determination, stamina and strength principles. Often the person was depicted with a smile on his face. These are the posters of Khrushchev's "corn campaign": "Corn - a source of plenty" (A. Lavrov, 1960), "Full speed to corn!" (A. Lavrov, 1961), "Corn - a source of further growth of our livestock" ( L. Golovanov, 1958). 


\section{Verbal picture messages of Soviet poster}

Posters usually transmit certain verbal communication also. It may be labeled as a "signature", "inscription", "slogan", and so on. Often message on the poster is laconic. Laconism of posters is justified. Poster reports at least "correct" information. You can select the following types of messages: a call ("Go ... to the complete victory of communism!", "Communists and Komsomol! Be at the forefront of ...”), a statement ("The working masses for us ..., "The people of the world do not want a repeat of the scourge of war"), equation ("Communism - Soviet government + electrician") and others. Any poster's message is minimized text. Linguists and semiologists study the text as the center of various codes. The code is a rule for combining and use of signs. The text of the poster is the result of coding. A poster's message seems to be very easy to understand. Otherwise, the poster wouldn't have so strong ideological influence. But even these brief messages combine different codes.

R. Barthes in his article "Textual analysis of a short story by Edgar Allan Poe", identified several codes: 1 . Code puzzles; 2. The symbolic code; 3. Scientific Code; 4 . Actional code; 5 . Code of rhetoric. I must add here the code of history. Different codes interact with one another. Very often even in a brief statement, multiple codes intersect. In the table below I show ordered information about the kinds of messages and the basic codes.

\begin{tabular}{|c|c|}
\hline Messages & Codes \\
\hline $\begin{array}{l}\text { Great Stalin-the Torch of } \\
\text { Communism! }\end{array}$ & $\begin{array}{l}\text { Dominant code - code of rhetoric. The metaphor - the } \\
\text { "torch". Historian P. Kovalevsky: "In the gloomy } \\
\text { darkness of Peter's reigns the only torch of hope in } \\
\text { Catherine." }\end{array}$ \\
\hline In the Name of Communism. & $\begin{array}{l}\text { Code of rhetoric. Idiom - "in the name." } \\
\text { Communism - causa finalis. Compare with the sign of } \\
\text { the cross: "In the Name of the Father ...". Stresses } \\
\text { goodness of targets "in the name of justice", ext. }\end{array}$ \\
\hline $\begin{array}{l}\text { Bring up a Worthy Generation of the } \\
\text { Communism' Builders! }\end{array}$ & $\begin{array}{l}\text { Actional code ("bring up"), appeal the necessity of joint } \\
\text { efforts. The rhetorical code ("worthy of builders"). }\end{array}$ \\
\hline Forward to Communism! & $\begin{array}{l}\text { Actional code. The words often denoting the imminent } \\
\text { action ("full speed ahead!"). Code of rhetoric. } \\
\text { Communism is not the line of the horizon and Fata } \\
\text { Morgana, but is an achievable goal. }\end{array}$ \\
\hline $\begin{array}{l}\text { Forward to the Victory of } \\
\text { Communism! }\end{array}$ & $\begin{array}{l}\text { Actional code. Its expression is not similar to the } \\
\text { previous case. Dichotomy of fighting, win/lose. } \\
\text { Communism is the purpose, for which you need to fight. } \\
\text { Designated dichotomy is strongly associated with the } \\
\text { assertion of an enemy's existence. But it reported no } \\
\text { hint. }\end{array}$ \\
\hline Under the Flag of Lenin, under the & Actional code ("forward", "leadership"). Code of history \\
\hline
\end{tabular}




\begin{tabular}{|c|c|}
\hline $\begin{array}{l}\text { Leadership of Stalin - Forward to a } \\
\text { New Flourishing of the Soviet } \\
\text { Motherland, to the Complete } \\
\text { Victory of Communism in our } \\
\text { Country! }\end{array}$ & $\begin{array}{l}\text { (the figure of V. Lenin). Code of rhetoric ("the flag of } \\
\text { Lenin", "leadership of Stalin", "new prosperity", } \\
\text { "complete victory"). Dichotomy of victory/defeat, } \\
\text { victory/fight sets off the dichotomy of a complete } \\
\text { victory/incomplete victory. Code of rhetoric expressed } \\
\text { opposition full/partial (incomplete), the phrase "partial } \\
\text { victory" and so on. Compare this with the recent } \\
\text { political news headline: "Minsk-2 is a partial victory of } \\
\text { Europe over the United States" }\end{array}$ \\
\hline $\begin{array}{l}\text { Heroic Work. Build up the Majestic } \\
\text { Building of Communism! }\end{array}$ & $\begin{array}{l}\text { Actional code (call to "build up"). Code of rhetoric } \\
\text { ("heroic work", "majestic building"). Difficult to find the } \\
\text { opposite: routine, everyday, ordinary? Communism is } \\
\text { materializing. Marker of materialization is the metaphor } \\
\text { of the "building". }\end{array}$ \\
\hline $\begin{array}{l}\text { Knowledge is the Path to } \\
\text { Communism. }\end{array}$ & Code of rhetoric (knowledge - "the way"). \\
\hline $\begin{array}{l}\text { For the Motherland! For Stalin! For } \\
\text { Peace! For Communism! }\end{array}$ & $\begin{array}{l}\text { Code of rhetoric. A single semiotic space has } 4 \text { poster } \\
\text { appeal. Each of them is relatively independent. The } \\
\text { sequence of labels can be non-deterministic. } \\
\text { Dependence of priority on the importance and values is } \\
\text { unlikely. }\end{array}$ \\
\hline $\begin{array}{l}\text { Glory to the Great Stalin - Architect } \\
\text { of Communism! }\end{array}$ & $\begin{array}{l}\text { Code of rhetoric. A trope (Stalin - "architect") is } \\
\text { designed to enhance the imagery of language. }\end{array}$ \\
\hline $\begin{array}{l}\text { The Mass of the Working People for } \\
\text { Us. This is Our Strength. This is } \\
\text { Source of the Invincibility of World } \\
\text { Communism. }\end{array}$ & $\begin{array}{l}\text { Code of rhetoric. Communism is labeled as "world" and } \\
\text { "invincible". Compare with the "Communist Manifesto": } \\
\text { "They have a world to win." (about proletarians) (Marx, } \\
\text { 1968: 69). }\end{array}$ \\
\hline $\begin{array}{l}\text { Lenin and Electrician. Volkhovstroy } \\
\text { Give Amperage! Communism - the } \\
\text { Soviet Government + Electrification. }\end{array}$ & $\begin{array}{l}\text { Three inscriptions make the poster' composition. The } \\
\text { transition from the leader's name to the name of the } \\
\text { company. The transition from the name of the } \\
\text { enterprise to the formula. Formula is an indicator of } \\
\text { accuracy, thoroughness judgments and conclusions. } \\
\text { Code of rhetoric. Code of history (the figure of V. Lenin, } \\
\text { Volkhovstroy). Actional code (the call). }\end{array}$ \\
\hline $\begin{array}{l}\text { Communists and Komsomol! Be the } \\
\text { First Ranks of the Fighters against } \\
\text { the Nazi Bloody Dogs. }\end{array}$ & $\begin{array}{l}\text { Code of rhetoric ("fighters", ext.). Trope (metaphor). } \\
\text { Humiliation of the enemy. }\end{array}$ \\
\hline $\begin{array}{l}\text { Young Builders of Communism! } \\
\text { Forward to New Successes in Work } \\
\text { and Study! }\end{array}$ & $\begin{array}{l}\text { Code of rhetoric. Often uses the metaphor of } \\
\text { "builders"/"architects". Marker "young". Actional code } \\
\text { expressed the slogan "Forward". }\end{array}$ \\
\hline
\end{tabular}




\begin{tabular}{|l|l|}
\hline $\begin{array}{l}\text { We Build Communism. We Live } \\
\text { under Communism. }\end{array}$ & $\begin{array}{l}\text { Code of rhetoric (statement, the pronoun in the dative } \\
\text { case as one of the markers of collectivism). Actional } \\
\text { code ("build", "live"). }\end{array}$ \\
\hline $\begin{array}{l}\text { Party Solemnly Declares: the } \\
\text { Current Generation of Soviet People } \\
\text { will Live Under Communism! }\end{array}$ & $\begin{array}{l}\text { Code of rhetoric (declaration). Actional code ("declares", } \\
\text { will live"). }\end{array}$ \\
\hline $\begin{array}{l}\text { According to the Leninist Path to } \\
\text { the Victory of Communism! }\end{array}$ & $\begin{array}{l}\text { Code of rhetoric (instead of Lenin's "flag" - Lenin's } \\
\text { "path"). Actional code (win/loss). Marker "forward" is } \\
\text { missing, but it can be mean. }\end{array}$ \\
\hline $\begin{array}{l}\text { Under the Leadership of the Great } \\
\text { Stalin - Forward to Communism! }\end{array}$ & $\begin{array}{l}\text { Code of rhetoric ("great" Stalin, exclamation). Actional } \\
\text { code ("forward"). }\end{array}$ \\
\hline $\begin{array}{l}\text { Under the Flag of Lenin, Under the } \\
\text { Leadership of Stalin - Forward to } \\
\text { Communism! }\end{array}$ & $\begin{array}{l}\text { Actional code. Its expression is identical to the previous } \\
\text { case. Code of rhetoric and code of history (a figure of V. } \\
\text { Lenin, "flag" of Lenin). Lenin's "flag" is a symbol of the } \\
\text { struggle for a brighter future. }\end{array}$ \\
\hline $\begin{array}{l}\text { A Spectre is Haunting Europe - the } \\
\text { Spectre of Communism }\end{array}$ & $\begin{array}{l}\text { Code of rhetoric (trails, repetition). Code of history } \\
\text { (quote the first line of "Manifesto" of K. Marx and F. } \\
\text { Engels) (Marx, 1968: 30). }\end{array}$ \\
\hline
\end{tabular}

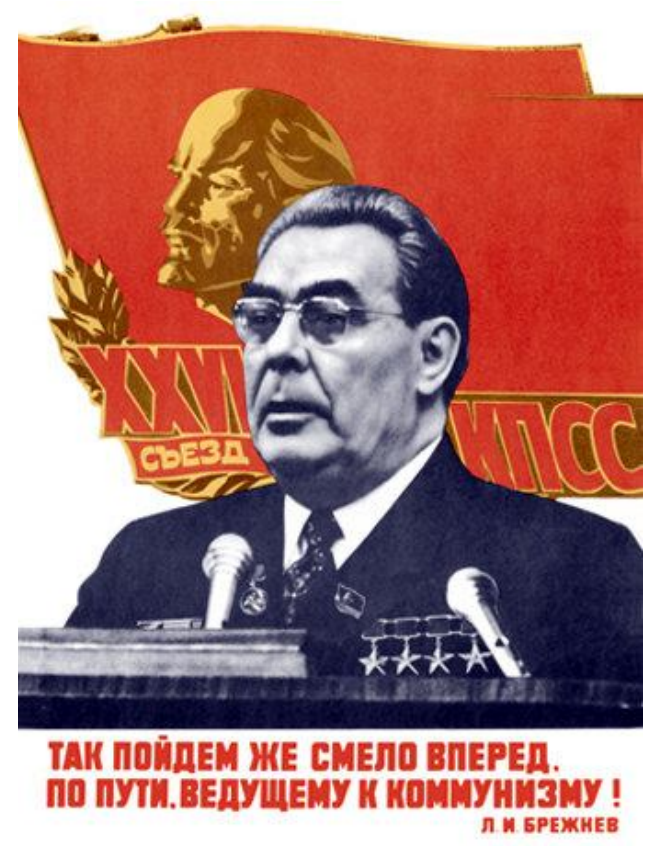

Figure 7: N. Popova's poster (1981)

A. Solomonik in the "The philosophy of sign systems and language", "Positive semiotics" and "The paradigm of semiotics" classified characters in their relationship with the sign systems. The poster is the reaction product of at least two systems - linguistic and iconic (figurative). In 
"The paradigm of semiotics" A. Solomonik wrote: "In second place are shaped system with its basic icon, which in some ways resembles depicted (isomorphic toward it)" (Solomonik, 2002: 113). Basic sign of language systems is more difficult. Language arises later than iconic. "Quantum abstract" of language systems is fundamentally different. In this case, we, in particular, are faced with the attitude of the sign to the referent. In the Soviet posters figures of the leaders are isomorphic to the referent. Stalin's image is similar to I. Stalin, who was imprinted by photographer and cameraman. Sometimes the makers of the posters used fragments of photos of the Secretaries-General. The result was a kind of collage, drawing and photographic material mixture; for example, N. Popova's poster (1981). The poster shows a fragment of photos of L. Brezhnev and depicts a developing flag with "bronze" Lenin's profile. Critics see the differences between different images of Stalin and other leaders of the party. Nevertheless, isomorphism is obvious. The image of Stalin is stylized. Styling is directly related to the increase in the distance between the icon and the referent.

Not all of the basic signs of Soviet posters are isomorphic to the referent. Sometimes the search for the referent is significantly impeded. Moreover, there are doubts about the existence of the referent. In the visual arts there are many cases of paintings and sculptures without the involvement of nature or photographic material. The figures in an abstract painting is a vivid example. Peasants in the paintings of K. Malevich, V. Kandinsky's Cossacks, P. Picasso's les demoiselles d'Avignon take abstract shapes. The Soviet Union is not always welcomed by abstraction. But the styling is not the prerogative of abstract and avant-garde. The stylized image of the Soviet people (builders of communism) is not uncommon and is not an exception. These images may be compared with the typical ancient Greek statues (kouros). They are like miniature netsuke carvings. Often they are performed using a knife. The artist did not try to recreate the details. Art historians know a lot of such examples. In the Soviet posters there also appeared stylized figures. One example is the poster "October opened the way into space" (V. Koretsky, 1960). In the foreground there is a worker. Light gray shade the face, large dark pupils, styled hair, bushy eyebrows, high cheekbones - all these and other features do not send the viewer to the referent. The man "stretches" to the scope of the audience with the coat of arms of the USSR. In the background a stylized image of a rocket - black "wedge". This "wedge" is like coming of the white circle (moon). The stylized images of the rocket and the moon are abstract. These images may be compared with the details of "Composition VIII" (V. Kandinsky, 1923). Two paintings (poster and "Composition") have quite different directions: wedge socialist realism and abstractionism. But "the charge of abstraction" in them is almost the same.

\section{Conclusion}

So I reviewed some of the iconic and verbal messages of the Soviet posters. All of them are directly or indirectly dedicated to the builder of communism. The poster is the result of a combination of the two systems - the language and image. The image of the Soviet human, therefore, is synthetic. It is constructed from the words and signs. Language, in comparison with visual images, has a large "charge of abstraction". Nevertheless, signs of posters have not often been associated with referents. The image of the leader of the state is isomorphic to the referent. Image of worker, on the contrary, has no isomorphism. Iconic message tended to increase in abstraction. This connects poster art with the canons of other areas, including the art of "pure" forms. Soviet poster is a zone of interaction of the various codes. The dominant codes are code of rhetoric and actional code. Code of history can not be considered dominant. At least, the examples considered here confirm this point. The building of communism is a matter of the present and the future, or, in the words of $\mathrm{F}$. Engels, is the "jump" in the "realm of freedom" (Engels, 1988: 145). The stylized figure of V. Lenin 
often occurred on the posters. It represented a thin connection to the past, heritage, history. Code of history closely related to code of rhetoric and to some extent depends on it.

\section{References}

Barth, Roland. "Ritorika obraza." Izbrannye Raboty: Semiotica: Poetica. Moskva: Progress, 1989. 297-318.

Barth, Roland. “Tekstovyi Analiz Odnoi Novelly Edgara Po.” Izbrannye Raboty: Semiotica: Poetica. Moskva: Progress, 1989. 424-461.

Dymarczyk, Waldemar "The War on the Wall. Polish and Soviet War Posters Analysis." Qualitative. Sociology Review. 2014. 10 (4). 6-31.

Edele, Mark. "Paper Soldiers: the World of the Soldier Hero according to Soviet Wartime Posters". Jahrbücher für Geschichte Osteuropas. 47 (1). 89-108.

Kiaer, Christina. "Lyrical Socialist Realism.” October. 2014. 147. 56-77.

Kiaer, Christina. "Was Socialist Realism Forced Labour? The Case of Aleksandr Deineka in the 193os." Oxford Art Journal. 28 (3). 321-345.

Kukulin, Ilya. "Privatization of a Riot: "Second Life" of the Early Soviet Montage." Sign Systems Studies. 41 (23). 266-311.

Kuzmina, Violetta. "The Formation of Soviet Culture and Ideology by the Creative Intelligentsia of the Centralno-Chernozemnyi Region." Terra Sebus. 2014. 55-66.

Lptman, Yuri. “Text v Texte”. Stati po Semiotice Kultury i Isskustva. Sankt-Peterburg: Akademicheski Proekt, 2002. 58-78.

Marx, Karl. Manifesto of the Communist Party. Moskva: Izdatelstvo Politicheskoi Literatury, 1968

Solomonik, Abram. Paradigna Semiotica. Moskva: Izdatelstvo LKI, 2011.

Solomonik, Abram. Pozitivnaya Semiotica. Moskva: Izdatelstvo LKI, 2011.

Solomonik, Abram. Filosophia Znakovych System i Yazyk. Minsk: MET, 2002.

Florenky, Pavel. U Vodorazdelov Mysli. Moskva: ACT, 2009

Engels, Friedrich. Anti-Dühring. Moskva: Izdatelstvo Politicheskoi Literatury, 1988.

Artur Dydrov teaches Philosophy at South Ural State University in Chelyabinsk (Russia). He is the author of a book and several academic articles in philosophical anthropology and philosophy of culture. He is currently writing doctoral research on a future person in the society of utopias and dystopias.dydrovaa@gmail.com 